\title{
The Relationship Between Pre-Service Teachers' Critical Thinking Tendencies and Problem Solving Skills
}

\author{
Gürbüz OCAK * and Eray EĞMiR \\ Education Faculty, Afyon Kocatepe University, Afyonkarahisar, Turkey
}

\begin{abstract}
The aim of this study is to determine the relationship between pre-service teachers' critical thinking tendencies and problem solving skills. Besides, the other problem of the study is whether problem solving skills show significant difference according to the critical thinking tendency level and according to the compound effect of critical thinking tendency level with gender, department and grade level respectively. The sample of the study consists of 224 1st and 2nd grade pre-service teachers studying at Afyon Kocatepe University Education Faculty. The California Critical Thinking Disposition Inventory, which was developed by Facione and Giancarlo (1998) and adapted into Turkish by Kökdemir (2003) and Problem Solving Inventory, which was developed by Heppner and Petersen (1982) and adapted into Turkish by Şahin, Şahin and Heppner (1993) are used as means of data collection in the study. According to the findings of the study, a significant and positive relationship between pre-service teachers' critical thinking tendencies and problem solving skills was found. According to the pre-service teachers' critical thinking tendency level (low, positively, high), problem solving skills and sub-dimensions show a significant difference. However problem solving skills show no significant differences according to the compound effect of critical thinking tendency level with gender, department and grade level.
\end{abstract}

Keywords: critical thinking tendency, problem solving skill, pre-service teacher.

The leading tool human beings use to make sense of the world is thinking. Thinking activity is behind the most of the characteristics human beings have. Talking, discussing, making choices and a lot of acts like that are all directed by thinking (Neville, 1981).

All human beings think by their nature. But if they don't possess effective thinking skills, they often think biased, deficient and not goal oriented (Doğanay and Ünal, 2006). On the other hand, knowledge society that we live in in this century demands individuals that can examine information he/she encounters, thinks independently and takes different approaches to events. To put it in a different way, at the present time human beings should generate an elimination system for the information he/she gains. At this point, the mental process which human beings need to use as a reasonable filter is critical thinking. (Thayer and Bacon, 2000). So critical thinking is an important mental process for human beings that accord with

\footnotetext{
*E-mail: gocak@aku.edu.tr
} 
demands of the knowledge society.

Critical thinking is reasonable and reflective thinking focused on deciding what to believe or do (Ennis, 1991: 6). Critical thinking can be defined by the skill of taking the responsibility of his/her own ideas. For this purpose, individuals improve various criterion and standards to evaluate their thinkings and use this criterion and standards constantly in order to enhance the quality of their thoughts (Paul and Elder, 1994). Cüceloğlu (2003: 216-217) defines critical thinking as "active, organised mental process that is aimed at understanding ourselves and everything around us by being conscious of our own thinking processes, by considering others' opininons and by practicing our learnings". Halpern (2002: 37) has described critical thinking as ". . .thinking that is purposeful, reasoned, and goal directed - the kind of thinking involved in solving problems, formulating inferences, calculating likelihoods, and making decisions".

Critical thinking, as a kind of thinking, is mostly defined with regard to using specific skills. But only posessing some skills is not enough to perform them. An individual's tendency to use these skills is of the essence for critical thinking. Critical thinking tendency is the intrinsic motivation of thinking critically when someone faces a problem to solve, an idea to analyse or a situation to judge (Giancarlo, 2006). The approachment of an individual who has critical thinking tendency to specific issues, question and events can be characterized by these actions:

- clarity in stating the question or concern,

- orderliness in working with complexity,

- diligence in seeking relevant information,

- reasonableness in selecting and applying criteria,

- care in focusing attention on the concern at hand,

- persistence though difficulties are encountered,

- precision to the degree permitted by the subject and the circumstance (Facione, 1991).

According to John Dewey, problem is everything that confuses an individual, challenges his/her mind and makes the belief vague (Gelbal, 1991: 167-168). Bingham (2004: 24) defines problem as obstacles that inhibit the existing power of an human that is aimed at reaching a goal. In this regard, basically, problem solving is the process of overcoming the obstacles which are obviating to reach a goal (Morgan, 1999). From another angle, problem solving is moving beyond simply implementing the learned rules to solve problem and finding new ways for that purpose (Korkut, 2002).

Problem solving skill includes understanding and restricting a problem, choosing the proper method for its solution, using this method and analysing the results when faced with a problem. When an individual acquires this skill, he/she gets into the habit of using problem solving to explain the situations, circumstances and events around him/her. (Altun, 2002). At this point the first and the most important activity for solving a problem is thinking. Thinking actitivty starts when one intuits a problem and solving that problem becomes a target for that individual; as a result, this objective directs individual's thinking. Thus, thinking activity that begins with intuiting problem consists of a process (Kalayc1, 2001). Within this period, an individual needs to use higher order thinking skills. An individual who aims to overcome different types of problems has to be a creative, reflective, critical and analytical thinker (Bilen, 1996). 
In the light of this information, critical thinking plays a significant role in problem solving process. Because in today's world, an individual who encounters many problems has to think critically for choosing proper knowledge and organise that knowledge which is obtained while realising the problem, characterising the problem and finding a solution to the problem phases. In this way, the individual can obtain proper data set for the problem, examine the reliability of this data set, classify it according to proper criterion, make logical deductions out of this data set and take responsibility for the judgements which were made in thinking process.

In the literature there are some studies that investigate the relationship between critical thinking tendecies and problem solving skills. Some of these studies are on pre-service teachers (Özcan, 2007; Gürleyük, 2008; Şara, 2012; Kasımoğlu, 2013; Berkant and Eren, 2013), and some others are on undergraduate students that study at different faculties (Hanley, 1995; Kökdemir, 2003; Tümkaya, Aybek and Aldağ, 2009). Besides, some researchers researched teachers (Turan, 2010) and students from different levels (Enright and Beattie, 1992); in addition some researchers handle this subject theoratically (Mumford, Mederious and Partlow, 2012; Leighton and Sternberg, 2013).

The problems of this study stated below;

- 1. Is there a significant relationship between the critical thinking tendencies and the problem solving skills of pre-service teachers?

- 2. Is there a significant difference between the problem solving skills and the subdimensions of Problem Solving Inventory of pre-service teachers according to the critical thinking tendency level (low, positively, high)?

- 3 . Is there a significant difference between the problem solving skills of pre-service teachers according to the compound effect of critical thinking tendency level and
a) gender,
b) department,
c) grade level?

\section{Method}

In this study the descriptive research model was chosen to respond the main problem and sub-problems of the study. The study was structured as a relational screening model to explore the relationship between critical thinking tendencies and problem solving skills. Relational screening is a research model which aims to determine the existence and/or degree of joint variation between two or more variants (Karasar, 2008: 79).

\section{Participants}

The population of the study consists of 1200 students who study at Afyon Kocatepe University Education Faculty 1st and 2nd class. The sample of the study was 224 students chosen out of the population by the stratified sampling method. Stratified sampling is a probability sampling technique wherein the researcher divides the entire population into different subgroups or strata and randomly selects the final subjects proportionally from the different strata (Yıldırım and Şimşek, 2005: 105). Below in Table 1 the distribution of sample according to the variables is given. 
Table 1. Sample Distribution

\begin{tabular}{llcc}
\hline Variable & & $\mathrm{f}$ & $\%$ \\
\hline \multirow{3}{*}{ Gender } & Female & 167 & 74.6 \\
\cline { 2 - 4 } & Male & 57 & 25.4 \\
\cline { 2 - 4 } & Total & 224 & 100 \\
\hline \multirow{5}{*}{ Department } & Preschool Teaching & 65 & 29 \\
\cline { 2 - 4 } & Primary School Teaching & 46 & 20.5 \\
\cline { 2 - 4 } & Social Sciences Teaching & 43 & 19.2 \\
\cline { 2 - 4 } & Science Teaching & 37 & 16.5 \\
\cline { 2 - 4 } & Turkish Teaching & 33 & 14.7 \\
\cline { 2 - 4 } Grade Level & Total & 224 & 100 \\
\cline { 2 - 4 } & 1st Grade & 110 & 49.1 \\
\cline { 2 - 4 } & 2nd Grade & 224 & 100 \\
\hline & Total & & \\
\hline
\end{tabular}

\section{Instruments}

The first instrument used in this study is California Critical Thinking Disposition Inventory (CCTDI-T). CCTDI-T ${ }^{1}$, developed by Facione and Giancarlo (1998) and adapted into Turkish by Kökdemir (2003). The original form of the inventory includes 75 items. The Turkish version of the original scale contains 51 items and has 6 subscales which are Analyticity, Open-mindedness, Inquisitiveness, Self-confidence, Truth-seeking, Systematicty. A score of 40 and below on any of the six subscales indicates consistent opposition or weakness to that given disposition while a score of 50 or higher represents a positive impact of that attribute. A total score above 240 reflects a positive overall disposition toward critical thinking (Kökdemir, 2003). In this study none of pre-service teachers have high critical thinking tendency. Hence the study has been conducted on two levels of critical thinking tendency (low, positively). Cronbach alpha reliability coefficient of The California Critical Thinking Disposition was found as .84 and according to this result, inventory has a high level of reliability (Tavşanc1l, 2006: 29).

The second insturment used in the study is Problem Solving Inventory. PSI ${ }^{2}$ developed by Heppner and Petersen (1982) and adapted into Turkish by Şahin, Şahin and Heppner (1993). PSI contains 35 items and 6 subscales which are Impulsive Style, Reflective Style, Avoidant Style, Monitoring, Problem-Solving Confidence, Planfulness. Cronbach alpha reliability coefficient of the total inventory and of each sub-scales which were found in the original study, in other studies and in this study are given in Table 2.

Table 2. Cronbach alpha reliability coefficient of original inventory, of other studies and of this study

${ }^{1}$ In this study to use the inventory adapted by Kökdemir (2003), permission has been taken from the researcher.

${ }^{2}$ In this study to use the inventory adapted by Şahin, Şahin and Heppner (1993), permission has been taken from the researcher. 


\begin{tabular}{ccccc}
\hline Sub-Scales & $\begin{array}{c}\text { Number of } \\
\text { Items }\end{array}$ & $\begin{array}{c}\text { Original Inventory } \\
(\alpha)\end{array}$ & $\begin{array}{c}\text { Berkant and Eren } \\
(2013) .(\alpha)\end{array}$ & This study $(\alpha)$ \\
\hline Impulsive Style & 9 & .78 & .68 & .71 \\
\hline Reflective Style & 5 & .76 & .80 & .77 \\
\hline Avoidant Style & 4 & .74 & .77 & .68 \\
\hline Monitoring & 3 & .69 & .67 & .70 \\
\hline Problem-Solving Confidence & 6 & .64 & .69 & .67 \\
\hline Planfulness & 4 & .59 & .67 & .86 \\
\hline Total & 35 & .88 & .87 & .68 \\
\hline
\end{tabular}

As seen in Table 2, Cronbach alpha reliability coefficient of the total inventory was found as .86. Internal consistencies of sub-scales varied between .68 and .77. When Cronbach alpha reliability coefficient of the total inventory was compared with the other studies, it was seen that the values are close to the values found by Şahin, Şahin and Heppner (1993). These values indicate that inventory has a high level of reliability (Tavşanc1l, 2006: 29).

\section{Process and Analysis of Data}

Data were obtained from pre-service teachers through the inventories and an information form; however, data from 7 participants were not evaluated since there was missing information in their forms. The inventories were analysed on a statistical programme. The relationship between critical thinking tendencies and problem solving skills of preservice teachers was examined by bivariate correlation. The difference between problem solving skills and sub-dimensions of Problem Solving Inventory of pre-service teachers according to the critical thinking tendency level (low, positively, high) was examined by independent samples t-test according to normality test. The difference between the problem solving skills of pre-service teachers according to the compound effect of critical thinking tendency level and gender, department and grade level respectively was examined by twoway Anova according to normality test.

\section{Findings}

\section{Is there a significant relationship between the critical thinking tendencies and the} problem solving skills of pre-service teachers?

The results of Pearson correlation analysis to examine whether there is a significant relationship between the critical thinking tendencies and the problem solving skills of preservice teachers are shown in Table 3.

Table 3. Correlation Analysis between the critical thinking tendencies and the problem solving skills of pre-service teachers

\begin{tabular}{cccc}
\hline & & $\begin{array}{c}\text { Critical Thinking } \\
\text { Tendencies }\end{array}$ & Problem Solving Skills \\
\hline \multirow{2}{*}{$\begin{array}{c}\text { Critical Thinking } \\
\text { Tendencies }\end{array}$} & $\mathbf{P}$ & 1,00 &, $69^{*}$ \\
\cline { 2 - 4 } & $\mathbf{N}$ & 224 &, 00 \\
\cline { 2 - 4 } Problem Solving Skills & $\mathbf{P}$ &, $69^{*}$ & 224 \\
\cline { 2 - 4 } & $\mathbf{P}$ &, 00 & 1,00 \\
\cline { 2 - 4 } & $\mathbf{N}$ & 224 & 224 \\
\hline
\end{tabular}


As shown in Table 3, a significant and positive relationship was found between critical thinking tendencies and problem solving skills of pre-service teachers $(r=, 69 ; p<.05)$. For this reason, this suggests that when critical thinking tendencies of pre-service teachers increases, the problem solving skills of pre-service teachers increases, too.

\section{Is there a significant difference between the problem solving skills and the sub-}

dimensions of Problem Solving Inventory of pre-service teachers according to the critical thinking tendency level (low, positively, high)?

The scores of pre-service teachers' which were taken from California Critical Thinking Disposition Inventory were classified as low and positively and to examine whether there is a significant difference between the problem solving skills and the sub-dimensions of Problem Solving Inventory of pre-service teachers according to the critical thinking tendency level (low, positively, high), independent samples t-test was conducted. The results are given in Table 4.

Table 4. Distribution of data related to problem solving skills of pre-service teachers according to the critical thinking tendency level

\begin{tabular}{|c|c|c|c|c|c|c|c|}
\hline Dimension & Level & $\mathrm{N}$ & $\bar{x}$ & SD & Df & $\mathrm{t}$ & $\mathrm{p}$ \\
\hline \multirow[b]{2}{*}{ Problem Solving Skill } & Low & 201 & 124,09 & 17,40 & \multirow[b]{2}{*}{32,632} & \multirow[b]{2}{*}{$-10,69$} & \multirow[b]{2}{*}{$*, 00$} \\
\hline & Positively & 23 & 153,21 & 12,51 & & & \\
\hline \multirow[b]{2}{*}{ Impulsive Style } & Low & 201 & 29,84 & 5,83 & \multirow[b]{2}{*}{222} & \multirow[b]{2}{*}{$-3,953$} & \multirow[b]{2}{*}{$*, 00$} \\
\hline & Positively & 23 & 34,95 & 6,19 & & & \\
\hline \multirow{2}{*}{ Reflective Style } & Low & 201 & 21,57 & 4,31 & \multirow{2}{*}{35,696} & \multirow{2}{*}{$-7,601$} & \multirow{2}{*}{$*, 00$} \\
\hline & Positively & 23 & 26,52 & 2,76 & & & \\
\hline \multirow{2}{*}{ Avoidant Style } & Low & 201 & 14,49 & 3,19 & \multirow{2}{*}{222} & \multirow{2}{*}{$-4,369$} & \multirow{2}{*}{$*, 00$} \\
\hline & Positively & 23 & 17,56 & 3,23 & & & \\
\hline \multirow{2}{*}{ Monitoring } & Low & 201 & 13,19 & 2,84 & \multirow{2}{*}{43,896} & \multirow{2}{*}{$-9,057$} & \multirow{2}{*}{$*, 00$} \\
\hline & Positively & 23 & 16,52 & 1,47 & & & \\
\hline \multirow{2}{*}{$\begin{array}{l}\text { Problem-Solving } \\
\text { Confidence }\end{array}$} & Low & 201 & 24,63 & 4,74 & \multirow{2}{*}{32,149} & \multirow{2}{*}{$-8,985$} & \multirow{2}{*}{$*, 00$} \\
\hline & Positively & 23 & 31,82 & 3,48 & & & \\
\hline \multirow{2}{*}{ Planfulness } & Low & 201 & 17,28 & 3,23 & \multirow{2}{*}{42,380} & \multirow{2}{*}{$-10,046$} & \multirow{2}{*}{$*, 00$} \\
\hline & Positively & 23 & 21,56 & 1,72 & & & \\
\hline
\end{tabular}

As shown in Table 4, there is a significant difference between the problem solving skills and the sub-dimensions of Problem Solving Inventory of pre-service teachers according to the 
critical thinking tendency level (low, positively) $(\mathrm{p}<.05)$. Therefore when means were examined pre-service teachers'problem solving skills, who have positive critical thinking tendency, are significantly higher than pre-service teachers' who have low critical thinking tendency

\section{Is there a significant difference between the problem solving skills of pre-service}

\section{teachers according to the compound effect of critical thinking tendency level and}

a) gender,

b) department,

c) grade level?

In this problem to examine whether there is a significant difference between the problem solving skills of pre-service teachers according to the compound effect of critical thinking tendency level and gender, department and grade level respectively, two-way Anova was conducted. Results are given in Table $6 a, 6 b, 7 a, 7 b$ ve $8 a, 8 b$.

Table 6a. Descriptive statistics related to problem solving skills of pre-service teachers according to the compound effect of critical thinking tendency level and gender

\begin{tabular}{ccccccccccc}
\hline & \multicolumn{3}{c}{ Low } & \multicolumn{1}{c}{ Positively } & \multicolumn{2}{c}{ Total } \\
\hline \multirow{2}{*}{ Gender } & $\mathrm{N}$ & $\bar{x}$ & $\mathrm{SD}$ & $\mathrm{N}$ & $\bar{x}$ & $\mathrm{SD}$ & $\mathrm{N}$ & $\frac{x}{2}$ & $\mathrm{SD}$ \\
\hline Fermale & 105 & 124,31 & 17,75 & 17 & 155,11 & 12,24 & 167 & 127,44 & 19,61 \\
\hline Male & 51 & 123,45 & 16,49 & 6 & 147,83 & 12,76 & 57 & 126,01 & 17,73 \\
\hline
\end{tabular}

Table 6b. Results of two-way Anova related to problem solving skills of pre-service teachers according to the compound effect of critical thinking tendency level and gender

\begin{tabular}{cccccc}
\hline Source of Variance & $\begin{array}{c}\text { Sum of } \\
\text { Squares }\end{array}$ & Df & Mean Square & F & p \\
\hline Gender & 263,61 & 1 & 263,61 &, 90 &, 34 \\
\hline Critical Thinking Tendency Level & 12096,88 & 1 & 12096,88 & 41,73 &, 00 \\
\hline Gender*CTTL & 163,81 & 1 & 163,81 &, 56 &, 45 \\
\hline Error & 63769,49 & 220 & 289,86 & & \\
\hline Corrected Total & 81537,38 & 223 & & & \\
\hline
\end{tabular}

As a result of two-way Anova, a significant difference between problem solving skills of preservice teachers according to the compound effect of critical thinking tendency level and gender was not found $[\mathrm{F}(1,220)=, 56 ;(\mathrm{p}>.05)]$. In other words, problem solving skills of female pre-service teachers do not differentiate significantly from male pre service teachers' problem solving skills according to the critical thinking tendency. Pre-service teachers' problem solving skills do not show a significant difference according to the gender variable, too $[\mathrm{F}(1,220)=, 90 ;(\mathrm{p}>.05)]$. In spite of this problem solving skills of pre-service teachers show a significant difference according to the critical thinking tendency $[F(1,220)=41,73$; $(\mathrm{p}<.05)]$.

Table 7a. Descriptive statistics related to problem solving skills of pre-service teachers according to the compound effect of critical thinking tendency level and department

\begin{tabular}{ccccccccccc}
\hline & \multicolumn{3}{c}{ Low } & \multicolumn{1}{c}{ Positively } & \multicolumn{3}{c}{ Total } \\
\hline Department & $\mathrm{N}$ & $\bar{x}$ & $\mathrm{SD}$ & $\mathrm{N}$ & $\bar{x}$ & $\mathrm{SD}$ & $\mathrm{N}$ & $\frac{x}{x}$ & $\mathrm{SD}$ \\
\hline Preschool Teaching & 59 & 127,22 & 17,87 & 6 & 155,83 & 11,32 & 65 & 129,86 & 19,21 \\
\hline Primary School & 43 & 120,83 & 16,32 & 3 & 150,33 & 4,50 & 46 & 122,76 & 17,43 \\
\hline
\end{tabular}




\begin{tabular}{cccccccccc}
\hline Teaching & \multicolumn{1}{c}{10} & & & & & & \\
\hline $\begin{array}{c}\text { Social Sciences } \\
\text { Teaching }\end{array}$ & 36 & 122,66 & 17,28 & 7 & 155,42 & 12,12 & 43 & 128,00 & 20,49 \\
\hline Science Teaching & 34 & 126,41 & 14,52 & 3 & 152,00 & 19,67 & 37 & 128,48 & 16,28 \\
\hline Turkish Teaching & 29 & 121,62 & 20,66 & 4 & 148,50 & 17,48 & 33 & 124,87 & 21,94 \\
\hline
\end{tabular}

Table 7b. Results of two-way Anova related to problem solving skills of pre-service teachers according to the compound effect of critical thinking tendency level and department

\begin{tabular}{cccccc}
\hline Source of Variance & $\begin{array}{c}\text { Sum of } \\
\text { Squares }\end{array}$ & Df & Mean Square & $\mathrm{f}$ & $\mathrm{P}$ \\
\hline Department & 473,39 & 4 & 118,34 &, 40 &, 80 \\
\hline Critical Thinking Tendency Level & 15128,80 & 1 & 15128,80 & 51,90 &, 00 \\
\hline Department*CTTL & 131,36 & 4 & 32,84 &, 11 &, 97 \\
\hline Error & 62373,27 & 214 & 291,46 & & \\
\hline Corrected Total & 81537,38 & 223 & & & \\
\hline
\end{tabular}

As a result of two-way Anova, a significant difference between the problem solving skills of pre-service teachers according to the compound effect of critical thinking tendency level and department was not found $[\mathrm{F}(4,214)=, 11 ;(\mathrm{p}>.05)]$. In other words, problem solving skills of pre-service teachers who study at different departments do not differentiate significantly according to the critical thinking tendency. Pre-service teachers' problem solving skills do not show a significant difference according to the department variable, too $[\mathrm{F}(4,214)=, 40$; $(\mathrm{p}>.05)]$. In spite of this problem solving skills of pre-service teachers show a significant difference according to the critical thinking tendency $[\mathrm{F}(1,214)=51,90 ;(\mathrm{p}<.05)]$.

Table 8a. Descriptive statistics related to problem solving skills of pre-service teachers according to the compound effect of critical thinking tendency level and grade level

\begin{tabular}{cccccccccc}
\hline & \multicolumn{3}{c}{ Low } & \multicolumn{9}{c}{ Positively } & \multicolumn{2}{c}{ Total } \\
\hline \multirow{2}{*}{ Grade Level } & $\mathrm{N}$ & $\bar{x}$ & $\mathrm{SD}$ & $\mathrm{N}$ & $\bar{x}$ & $\mathrm{SD}$ & $\mathrm{N}$ & $\frac{x}{x}$ & $\mathrm{SD}$ \\
\hline 1st Grade & 97 & 127,56 & 15,83 & 13 & 154,30 & 11,57 & 110 & 130,72 & 17,62 \\
\hline 2nd Grade & 104 & 120,85 & 18,23 & 10 & 151,80 & 14,16 & 114 & 123,57 & 19,91 \\
\hline
\end{tabular}

Table 8b. Results of two-way Anova related to problem solving skills of pre-service teachers according to the compound effect of critical thinking tendency level and grade level

\begin{tabular}{cccccc}
\hline Source of Variance & $\begin{array}{c}\text { Sum of } \\
\text { Squares }\end{array}$ & Df & Mean Square & $\mathrm{f}$ & $\mathrm{p}$ \\
\hline Grade Level & 431,74 & 1 & 431,74 & 1,53 &, 21 \\
\hline Critical Thinking Tendency Level & 16904,17 & 1 & 16904,17 & 60,23 &, 00 \\
\hline Grade Level*CTTL & 89,76 & 1 & 89,76 &, 32 &, 57 \\
\hline Error & 61737,02 & 220 & 280,62 & & \\
\hline Corrected Total & 81537,38 & 223 & & & \\
\hline
\end{tabular}

As a result of two-way Anova a significant difference between the problem solving skills of pre-service teachers according to the compound effect of critical thinking tendency level and grade level was not found $[\mathrm{F}(1,220)=, 32 ;(\mathrm{p}>.05)]$. In other words, problem solving skills of pre-service teachers who study at 1 st grade do not differentiate significantly from pre service teachers' problem solving skills who study at 2 nd grade according to the critical thinking tendency. Pre-service teachers' problem solving skills do not show a significant difference according to the grade level variable, too $[\mathrm{F}(1,220)=1,53 ;(\mathrm{p}>.05)]$. In spite of this problem solving skills of pre-service teachers show a significant difference according to the critical thinking tendency $[\mathrm{F}(1,220)=60,23 ;(\mathrm{p}<.05)]$. 


\section{Results and Discussion}

When the results obtained from the study are examined, it is seen that a significant and positive relationship was found between the critical thinking tendencies and the problem solving skills of pre-service teachers $(\mathrm{r}=, 69 ; \mathrm{p}<.05)$. Today, individuals should have skills of distinguishing problems which they encounter, restricting these problems and using critical thinking in problem solving process in addition to many thinking skills, and also should have a tendency to use critical thinking in problem solving process. An individual can get information for solution and can come a long way for the solution of problem only by this way.

Similarly Kanbay, Aslan, Işık and Kılıç (2013) who studied on nursing undergraduate students, Tümkaya, Aybek and Aldağ (2009) on undergraduate students, Turan (2010) on primary school found a significant correlation between these two phenomena. Beside this, Enright and Beattie (1992) stated that critical thinking is an essential skill for problem solving in the conclusion part of their study. Leighton and Sternberg (2013) and Mumford, Mederious and Partlow (2012) pointed out in their theoritical study that critical and reflective thinking play an important role in increasing problem solving performance. Hanley (1995) concluded in the study that was carried out on undergraduate students that having critical thinking skills has a positive affect on approachments in problem solving process.

On the contrary Özcan (2007), stated in the study in which he examined the effect of the method of problem solving to pre-service teachers' critical thinking and achievement that problem solving method did not cause a difference in favor of expiremantal group's critical thinking. At the same time Gürleyük (2008) concluded that there is not a significant relationship between critical thinking tendency and problem solving skills in the study in which he studied on primary school pre-service teachers. The difference of the sample can be shown as a reason for the difference between conclusions.

Secondly a significant difference between the problem solving skills of pre-service teachers according to the critical thinking tendency level (low, positively) was found $(\mathrm{p}<.05)$. When means were examined, pre-service teachers' problem solving skills who have positive critical thinking tendency are higher significantly than pre-service teachers' who have low critical thinking tendency. Whereas a significant relationship between the critical thinking tendencies and the problem solving skills of pre-service teachers and a significant difference between the problem solving skills of pre-service teachers according to the critical thinking tendency level was found in this study, it can be said that these two results support each other. Similarly, Kökdemir (2003) stated that individuals who have high level of critical thinking tendency behave rationally in the process of making a decision, but however individuals who have low level of critical thinking tendency cut corners. Kökdemir (2003), in his study, indicated that individuals who have high level of critical thinking tendency make rational decisions not on all kinds of problems but especially on probability-based problems in comparison with individuals with low level of tendency.

In this study also a significant difference between the sub-dimensions of Problem Solving Inventory of pre-service teachers according to the critical thinking tendency level (low, positively) was found $(\mathrm{p}<.05)$. When means were examined pre-service teachers' scores of sub-dimensions of Problem Solving Inventory who have positive critical thinking tendency are higher significantly than pre-service teachers' who have low critical thinking tendency. 
When findings of this study is examined, problem solving skills show no significant difference according to the compound effect of critical thinking tendency level with gender, department and grade level. Beside this, gender, department and grade level variables do not cause a significant difference on pre-service teachers' problem solving skills on their own, too.

Similarly Tümkaya, Aybek and Aldağ (2009) stated that gender and field of study were not significant variables related to critical thinking disposition or to perceived problem solving skills. In addition to that Berkant and Eren (2013) who worked on elementary mathematics teachers, Kasımoğlu (2013) on pre-service teachers, Yenice, Özden and Evren (2012) on science pre-service teachers, Kirılmazkaya (2010) on science and primary school pre-service teachers and Ulusoy et al. (2012) on undergraduate students indicated that, gender and grade level do not cause a significant difference on pre-service teachers' problem solving skills

In spite of this, Şara (2012) who worked on primary school pre-service teachers found a significant difference related to the problem solving skills in favor of female pre-service teachers. Also, Gürleyük (2008), who worked on primary school pre-service teachers, found a significant difference related to the problem solving skills in favor of male pre-service teachers. In addition to this, pre-service teachers who study at 4th grade have a higher level of problem solving skills than pre-service teachers who study at other grades. Tümkaya, Aybek and Aldağ (2009) found a significant difference related to the problem solving skills between first and 4th grader students in favor of 4th grader students. In this study to include first and second grade students and students from different departments at the same time could make a difference on the conclusions. Also Ocak and Eğmir (2014) found a significant difference in problem solving skill and impulsive and avoidant sub-dimensions according to the gender, in problem solving skill and reflective, monitoring, problem-solving confidence and planfulness sub-dimenisons according to the grade level and in problem solving skill and impulsive subdimension according to the department.

\section{References}

Altun, M. (2002). İlkögrretim İkinci Kademede Matematik Öğretimi [Mathematics Instruction in Secondary Level]. İstanbul: Alfa Printing and Publishing.

Berkant, H. G. and Eren, İ. (2013). Investigating Problem Solving Skills of Students of Primary School Math Teaching Department In Terms of Some Variables. International Journal of Social Science, 6 (3), 1021-1041.

Bilen, M. (1996). Plandan Uygulamaya Öğretim [Instruction from Plan to Practice]. Ankara: Aydan Web Facilities.

Bingham, A. (2004). Çocuklarda Problem Çözme Yeteneklerinin Geliştirilmesi [Improving problem solving skills in children]. (Translated by A. Ferhan Oğuzkan), İstanbul: Ministry of National Education Publications, No: 3130.

Cüceloğlu, D. (2003). İyi Düşün Doğru Karar Ver [Think Carefully Give the Right Decision], İstanbul: Sistem Press.

Doğanay, A. and Ünal F. (2006). Eleştirel Düşünmenin Öğretimi [Instruction of Critical Thinking], Ali Şimşek (Ed). İçerik Türlerine Dayalı Ögretim [Instruction Based on Content Type]. Ankara: Nobel Press.

Elder, L. and Paul, R. 1994). Critical Thinking: Why We Must Transform Our Teaching. Journal of Developmental Education, 18 (1), 34-35.

Ennis, R. (1991). Critical Thinking: A Streamlined Conception. Teaching Philosophy, 14 (1), 5-24. 
Enright, B. E. and Beattie, S. A. (1992). Assessing Critical Thinking in Mathematics, Diagnostique, 17 (2), 137-144.

Facione, P. A. (1991). Critical Thinking: A Statement of Expert Consensus for Purposes of Educational Assessment and Instruction. Institute for Critical Thinking Resource Publication, Series 4, No. 6, Upper Montclair, NJ: Montclair State University.

Facione, P. A. and Facione, N. C. (1998). The California Critical Thinking Dispositions Inventory (CCTDI); and the CCTDI Test manual. Millbrae, CA: California Academic Press.

Gelbal, S. (1991). Problem solving. Hacettepe University Journal of Education, 6, 167-173.

Giancarlo, C. A. F. (2006). California Measure of Mental Motivation (CM3), An Inventory of Critical Thinking Dispositions, User Manual. CA: The California Academic Press LLC.

Gürleyük, G. C. (2008). The analysis of critical thinking disposition, problem solving abilities and academic achievement levels of primary school teacher candidates with respect to some variables. (Unpublished master's thesis). Zonguldak Karaelmas University Institute of Social Sciences, Zonguldak.

Halpern, D. F. (2002). Thought and knowledge: an introduction to critical thinking. (4th ed.). Mahwah, NJ: Lawrence Erlbaum Associates, Inc.

Hanley, G. L. (1995). Teaching Critical Thinking: Focusing on Metacognitive Skills and Problem Solving, Teaching of Psychology, 22 (1), 68-72.

Heppner, P.P. (1988). Problem Solving Inventory (PSI): Research Manual. Palo Alto, CA: Consulting Psychologists Press.

Kalaycı, N. (2001). Sosyal Bilimlerde Problem Çözme ve Uygulamalar [Problem Solving and Practices in Social Sciences]. Ankara: Gazi Press.

Kanbay, Y., Aslan, Ö., Işık, E. and Kılıç, N. (2013). Problem Solving and Critical Thinking Skills of Undergraduate Nursing Students. Journal of Higher Education and Science, 3 (3), 244-251.

Kasımoğlu, T. (2013). Evaluation of critical thinking, logical thinking and problem solving skills for teaching candidates from several variables angles (Unpublished master's thesis). Gazi University Institute of Education Sciences, Ankara.

Kirllmazkaya, G. (2010). The comparison between science and class of candidate teachers? social and problem solving skills (Unpublished master's thesis). Frat University Institute of Science, Elazı ğ.

Korkut, F. (2002). Problem Solving Skills of High School Students. Hacettepe University Journal of Education, 23, 177-184.

Kökdemir, D. (2003). Decision making and problem solving under uncertainty (Unpublished $\mathrm{PhD}$ Thesis). Ankara University Institute of Social Sciences. Ankara.

Leighton, J. P. and Sternberg, R. J. (2013). Reasoning and Problem Solving. Irving B. Weiner (Ed.), Handbook of Psychology içinde (s. 631-655). John Wiley \& Sons, Inc.

Morgan, C. T. (1999). Psikolojiye Giriş [Introduction to Psychology] (13.Print). (Translated by Hüsnü Arıcı et al.), Ankara: Meteksan Press.

Mumford, M. D., Medeiros, K. E. and Partlow, P. J. (2012). Creative Thinking: Processes, Strategies and Knowledge, The Journal of Creative Behavior, 46 (1), 30-47.

Neville, R.(1981). Reconstruction of thinking. Albany: State university of New York press.

Ocak, G. and Eğmir, E. (2014). Investigation of Pre Service Teachers' Problem Solving Skills In Terms of Different Variables. Asian Journal of Instruction, 2 (1), 27-45.

Özcan, G. (2007). Effect of the method of problem solving to critical thinking and achievement. (Unpublished PhD Thesis). Abant İzzet Baysal University Institute of Social Sciences, Bolu.

Şahin, N., Şahin, N. H. and Heppner, P. P. (1993). The psychometric properties of the Problem Solving Inventory. Cognitive Therapy and Research, 17 (4), 379-396. 
Şara, P. (2012). A study on primary school candidate teachers' learning and study strategies, problem solving skills and locus of control in terms of various variables (Unpublished $\mathrm{PhD}$ Thesis). Dokuz Eylül University Institute of Education Sciences, İzmir.

Tavşancıl, E. (2006). Tutumların Ölçülmesi ve SPSS ile Veri Analizi [Measurment of Attitudes and Data Analysis by SPSS]. Ankara: Nobel Press.

Thayer, B. and Bacon, T. (2000). Transforming critical thinking. New York: Teachers college press.

Turan, H. (2010). The network of explanatory interactions between constructive classroom teaching and creative thinking, problem-solving skills and critical thinking disposition. (Unpublished PhD Thesis). Y1ldız Teknik University Institute of Social Sciences, İstanbul.

Tümkaya, S., Aybek, B. and Aldağ, H. (2009). An Investigation of University Students' Critical Thinking Disposition and Perceived Problem Solving Skills, Eurasian Journal of Educational Research, 36, 57-74.

Ulusoy, Y.Ö., Turan, H., Tanrıverdi, B. and Kolayiş, H. (2012). Comparison of perceived problem solving skills of trainee students graduated from different. Procedia - Social and Behavioral Sciences, 46, 2099 - 2103.

Yenice, N., Özden, B. and Evren, B. (2012). Examining of problem solving skills according to different variables for science teachers candidates. Procedia - Social and Behavioral Sciences, 46, 3880 - 3884.

Yıldırım, A. and Şimşek, H. (2005). Sosyal bilimlerde nitel araştırma yöntemleri [Methods of Qualitative Research in Social Sciences]. Ankara: Seçkin Press. 